\title{
Stock Market Reactions To Sovereign Credit Rating Changes: Evidence From Four European Countries
}

Ibrahim Fatnassi, University of Tunis, Tunisia

Zied Ftiti, IPAG Business School, IPAG Lab, Paris France

Habib Hasnaoui, University of Tunis, Tunisia

\begin{abstract}
We analyze the reactions of the returns of four European stock markets to sovereign credit rating changes by Fitch, Moody's, and Standard and Poor's (S\&P) during the period from June 2008 to June 2012 using panel regression equations. We find that (i) upgrades and downgrades affect both own country returns and other countries' returns, (ii) market reactions to foreign downgrades are stronger during the sovereign debt crisis period, and (iii) negative news from rating agencies are more informative than positive news.
\end{abstract}

Keywords: Sovereign Credit Rating; Stock Markets; Reaction; Upgrades; Downgrades

\section{INTRODUCTION}

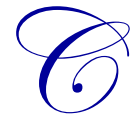

apital inflows to developing countries have been increasing since the mid-1990s. They have increased from $\$ 50$ billion per year between 1987 and 1989 to more than $\$ 150$ billion annually over the period from 1995 to 1997. Private flows came to represent $20 \%$ of domestic investment in developing countries in 1996, compared to only three percent in 1990. Currently, their level is about $28 \%$. This is a result of the removal of barriers to international capital flows as well as improvements in communication, which have reduced the cost of information about foreign securities. As a consequence, it has become critical for market players and firms seeking foreign funds to assess all the risks associated with raising funds in international markets.

As active investment decisions, the setting up of international portfolios requires several inputs. The related literature suggests that credit ratings are among the most important of these. Credit rating agencies are regarded as specialist information providers in international financial markets. In particular, they provide an overall appraisal of the creditworthiness of each country. Their assessments of sovereign and corporate entities have been used as benchmarks by governments and investors. This is particularly true in the case of institutional investors, who are required to invest in investment-grade instruments, which are usually defined being rated above BBB- and Baa3 by Standard and Poor's (S\&P) and Moody's, respectively.

The role of credit rating agencies in the international financial system has been the subject of deep debate. In 2003, the Basel Committee recommended the use of external credit ratings in its new Capital Accord. In other words, support from this accord has caused the role of credit agencies in international financial markets to become very important. However, experience has demonstrated the inadequacy of rating agencies, especially in the context of emerging markets. Specifically, it has been shown by both practitioners and academics that credit rating agencies are unable to predict periods of financial turmoil (such as the Asian financial or subprime crises). Indeed, Radelet and Sachs (1998) note that the actions of credit rating agencies have intensified and perhaps even prolonged crises. Additionally, Ferri et al. (1999) argue that these agencies exhibit pro-cyclical behavior, upgrading sovereign entities during boom times and downgrading them during periods of crisis. Similarly, Reisen and von Maltzan (1999) have argued that rating agencies contribute to boom-bust cycles in international financial markets, placing emerging markets at risk. However, such arguments are largely based on the assumption that sovereign ratings actually 
provide financial markets with new information, despite the fact that the current empirical evidence relating to this issue is far from conclusive. In particular, there are few studies focusing on the impact of rating agencies on asset prices (stock markets). These studies have found ambiguous evidence that rating agency signals actually impact security prices. Some studies support the notion that rating changes have a significant impact on stock markets (Cantor \& Packer, 1996; Reinhart \& Rogoff, 2004; Bissoondoyal-Bheenick, 2004; Kim \& Wu, 2008; Hooper et al., 2008; Bissoondoyal-Bheenick, 2012; Christopher et al., 2012; Treepongkaruna \& Wu, 2012), whereas others do not (Brooks et al., 2004; Ferreira \& Gama, 2007).

The aim of this study is to examine empirical evidence on the effect of sovereign credit rating changes by international credit rating agencies on the stock markets of the most volatile European countries (Greece, Portugal, Spain, and Italy) during the period from June 2008 to June 2012. More specifically, our objective is to determine whether rating changes in individual countries affect own-stock market returns as well as those of other neighboring countries, thereby transmitting the crisis to those countries.

Our interest in the question presented above is motivated by several factors. From a theoretical point of view, knowing the nature of the relationship between rating changes and stock markets allows us to better understand the price discovery process. From a practical point of view, "more knowledge on these issues has important implications for financial practices. Indeed, given the internationalization of investment portfolios, investment capital managers require greater and more accurate information on country risk. Consequently, it is important for these managers to be informed about the impact of rating changes on their portfolios.

Our study is very important from an international policy perspective. Given that rating changes provide new information on financial markets, the international rating agencies have the ability to intensify and prolong or, alternatively, to weaken financial crises. In addition, this study tests the efficacy of sovereign credit ratings as regulatory tools within the context of the new Basel Accord on Bank Capital Requirements.

The remainder of this paper is organized as follows. Section 2 describes the data and empirical methodology. Section 3 reports and discusses the results. Section 4 concludes the paper.

\section{DATA AND EMPIRICAL METHODOLOGY}

Our sovereign credit rating data for the period from June 1, 2008, to June 7, 2012 are taken from the three agencies that dominate the credit rating business: S\&P, Moody's, and Fitch (Duff \& Einig, 2009; Alsakka \& Gwilym, 2010). Moody's and S\&P account for $80 \%$ of the market, while Fitch's share is $15 \%$. This time-frame was chosen because several credit rating changes took place during this period (see Table 1). We focus on the four European countries affected by sovereign debt crises: Greece, Spain, Portugal, and Italy. Other economies, such as France, Germany, and the United Kingdom, are not included in our sample because their sovereign credit ratings did not experience significant changes during the selected period. The data are compiled using the Bloomberg database. We collected daily stock market indices for the four countries using the Morgan Stanley Capital International database. Stock returns are calculated as the log difference of stock indices and expressed in percentages.

In order to quantify credit rating changes, we assign numerical values to letter credit ratings, similar to Christopher et al. (2012), Ferreira and Gama (2007), Gande and Parsley (2005), and Li et al. (2007). For letter credit ratings, we create a ratings scale ranging from 0 to 20 , with the AAA rating taking the highest value and NR, WR, and C, for S\&P, Moody's, and Fitch, respectively, taking the lowest value. ${ }^{1}$ Then, we create dummy variables for own-country as well as foreign upgrades and downgrades.

\footnotetext{
${ }^{1}$ Afonso et al. (2012) use a linear scale to group ratings into 17 categories, where AAA is attributed to the 17th level and decreasing intervals of 1 reach until below B-. Bennell et al. (2006) use the same rating scales but employ a range of 1 to 16, where decreasing intervals of 1 reach until Bor below. Sy (2004) assigns scores from 1 to 58 with an interval of 3 . Li et al. (2008) use a total of 22 notches, where 20 is assigned to the highest rating, AAA, and a value of 0 is assigned to the lowest, SD.
} 
For a given time $t$ and country $i$, the dummy variables $u p$ and $d w$ take the following values:

$u p_{i t}= \begin{cases}1, & \text { if an upgrade occurs } \\ 0, & \text { otherwise }\end{cases}$

$d w_{i t}= \begin{cases}1, & \text { if a downgrade occurs } \\ 0, & \text { otherwise }\end{cases}$

In addition to the up and $d w$ dummy variables, we consider rating changes in foreign countries. The dummy variables frup and $f r d w$ take the following values:

Frup $_{i t}=\left\{\begin{array}{l}1, \text { if an upgrade occurs for any other } \\ \text { countries }(\text { except country } i)\end{array}\right.$
otherwise

Table 1 summarizes ratings changes over the entire sample period and during the sovereign debt crisis period ranging from June 17, 2008, to June 7, 2012.

Table 1: Summary of Rating Activity

\begin{tabular}{|c|c|c|c|c|}
\hline & $\begin{array}{l}\text { Number of } \\
\text { upgrades }\end{array}$ & $\begin{array}{l}\text { Number of } \\
\text { downgrade }\end{array}$ & $\begin{array}{c}\text { Number of foreign } \\
\text { upgrades }\end{array}$ & $\begin{array}{c}\text { Number of foreign } \\
\text { downgrade }\end{array}$ \\
\hline \multicolumn{5}{|c|}{ Panel A: Whole Sample 01/06/2008 - 07/06/2012 } \\
\hline Greece & 5 & 24 & 3 & 30 \\
\hline Portugal & 0 & 15 & 8 & 41 \\
\hline Spain & 2 & 13 & 6 & 43 \\
\hline Italy & 1 & 8 & 7 & 48 \\
\hline \multicolumn{5}{|c|}{ Panel B: Sovereign Debt Crisis Period 17/06/2010-07/06/2012 } \\
\hline Greece & 2 & 13 & 0 & 21 \\
\hline Portugal & 0 & 11 & 2 & 25 \\
\hline Spain & 0 & 10 & 2 & 27 \\
\hline Italy & 0 & 6 & 2 & 31 \\
\hline
\end{tabular}

In order to study the reactions of stock market equity returns to sovereign rating upgrades and downgrades across these four European countries, we estimate the following two panel regression equations:

$r_{i t}=\alpha_{i}+\alpha_{1} r_{i t-1}+\alpha_{2} r_{U S t-1}+\sum_{j=-4}^{4} \beta_{j} u p_{i t-j}+\sum_{j=-4}^{4} \gamma_{j} d w_{i t-j}+\varepsilon_{i t}$

$r_{i t}=\alpha_{i}+\alpha_{1} r_{i t-1}+\alpha_{2} r_{U S, t-1}+\sum_{j=-4}^{4} \beta_{j} u p_{i t-j}+\sum_{j=-4}^{4} \gamma_{j} d w_{i t-j}+\sum_{j=-2}^{2} \pi_{j} f_{r u p} i t-j+\sum_{j=-2}^{2} \tau_{j} f r d w_{i t-j}+\varepsilon_{i t}$,

where $r_{i t}$ and $r_{U S t-1}$ represent the stock market return in country $i$ at time $t$ and that in the United States (US) at time $t-1$, respectively. $u p_{i t}, d w_{i t}, f_{r u p}$, and $f r d w_{i t}$ respectively represent upgrades in the own country, downgrades in the own country, upgrades in foreign countries, and downgrades in foreign countries. Four-day lags and leads for own-country rating changes are included in both Equations (1) and (2). In Equation (2), which examines the contagion effect, we include only foreign upgrades and downgrades with two-day lags and two-day leads in order to avoid over-parameterization. The coefficient of foreign rating changes in Equation (2) (foreign upgrades and downgrades) measures the contagion effect.

Leads in Equations (1) and (2) are used in order to test the pro-market-performance behavior of the credit rating agencies ( $\mathrm{Li}$ et al., 2007). According to this hypothesis, the credit rating agencies follow market performance: they upgrade their credit ratings when markets are already booming and downgrade them only after markets have entered a slump. 


\section{ESTIMATIONS AND RESULTS}

Table 2 reports the estimated coefficients of Equations (1) and (2). These estimations ${ }^{2}$ are conducted for both periods. The first estimation is realized for the entire sample period (June 2008 - June 2012) in order to evaluate overall stock market reactions. A second estimation is conducted for the debt crisis period (June $2010-$ June 2012) in order to focus only on the stock market reaction to sovereign credit rating changes during the debt crisis period.

There is evidence that sovereign debt rating change announcements affect stock markets. The autoregressive term coefficients, $\alpha_{1}$, are negative and statistically significant, indicating a negative autocorrelation of stock returns. The coefficients on changes in US stock returns are all positive and significant, providing evidence that the US market has a strong impact.

Table 2: The Impact of Own and Foreign Rating Changes on Stock Returns

\begin{tabular}{|c|c|c|c|c|c|c|c|c|}
\hline & \multicolumn{4}{|c|}{ Eq. (1) } & \multicolumn{4}{|c|}{ Eq. (2) } \\
\hline & \multicolumn{2}{|c|}{ Whole Period } & \multicolumn{2}{|c|}{$\begin{array}{c}\text { Sovereign Debt } \\
\text { Crisis Period }\end{array}$} & \multicolumn{2}{|c|}{ Whole Period } & \multicolumn{2}{|c|}{$\begin{array}{c}\text { Sovereign Debt } \\
\text { Crisis Period }\end{array}$} \\
\hline & Coefficient & $P$-value & Coefficient & $P$-value & Coefficient & $P$-value & Coefficient & p-value \\
\hline$\overline{\alpha_{i}}$ & $-0.049 * * *$ & 0.005 & $-0.046 * * *$ & 0.004 & $-0.049 * * *$ & 0.003 & $-0.041 * * *$ & 0.004 \\
\hline$\alpha_{1}$ & $-0.040 * * *$ & 0.001 & $-0.040 * * *$ & 0.002 & $-0.041 * * *$ & 0.001 & $-0.040 * * *$ & 0.002 \\
\hline$\alpha_{2}$ & $0.057 *$ & 0.015 & $0.038 *$ & 0.096 & $0.058^{* *}$ & 0.014 & $0.039 *$ & 0.094 \\
\hline \multicolumn{9}{|l|}{ Upgrades } \\
\hline $\operatorname{Lag} 0$ & 0.693 & 0.252 & 0.667 & 0.222 & 0.863 & 0.246 & 0.858 & 0.215 \\
\hline $\operatorname{Lag} 1$ & $1.008^{*}$ & 0.096 & $1.003 *$ & 0.066 & 0.778 & 0.296 & 0.766 & 0.268 \\
\hline $\operatorname{Lag} 2$ & $-1.029 *$ & 0.089 & $-1.056^{*}$ & 0.053 & -0.918 & 0.218 & -0.961 & 0.166 \\
\hline $\operatorname{Lag} 3$ & -0.579 & 0.338 & -0.586 & 0.283 & -0.590 & 0.329 & -0.591 & 0.279 \\
\hline $\operatorname{Lag} 4$ & 0.277 & 0.646 & 0.272 & 0.619 & 0.261 & 0.666 & 0.269 & 0.623 \\
\hline Lead 1 & -0.655 & 0.279 & -0.689 & 0.207 & -0.246 & 0.741 & -0.258 & 0.709 \\
\hline Lead 2 & -0.415 & 0.492 & -0.401 & 0.463 & -0.606 & 0.416 & -0.585 & 0.398 \\
\hline Lead 3 & -0.051 & 0.933 & -0.051 & 0.925 & -0.070 & 0.907 & -0.055 & 0.919 \\
\hline Lead 4 & 0.388 & 0.521 & 0.369 & 0.499 & 0.373 & 0.537 & 0.360 & 0.510 \\
\hline \multicolumn{9}{|l|}{ Downgrades } \\
\hline Lag 0 & -0.125 & 0.453 & -0.106 & 0.526 & -0.019 & 0.925 & -0.040 & 0.840 \\
\hline $\operatorname{Lag} 1$ & 0.272 & 0.104 & $0.284 *$ & 0.087 & $0.445 * *$ & 0.030 & $0.337 *$ & 0.093 \\
\hline $\operatorname{Lag} 2$ & $-0.414 *$ & 0.013 & -0.052 & 0.754 & -0.328 & 0.109 & -0.063 & 0.753 \\
\hline $\operatorname{Lag} 3$ & $0.316^{*}$ & 0.058 & -0.036 & 0.829 & $0.307 *$ & 0.066 & -0.042 & 0.799 \\
\hline $\operatorname{Lag} 4$ & -0.119 & 0.475 & $-0.337 * *$ & 0.043 & -0.131 & 0.435 & $-0.342^{* *}$ & 0.040 \\
\hline Lead 1 & $-0.592 * *$ & 0.000 & $-0.687 * * *$ & 0.000 & $-0.933 * * *$ & 0.000 & $-0.997 * * *$ & 0.000 \\
\hline Lead 2 & -0.277 & 0.096 & 0.005 & 0.974 & -0.305 & 0.137 & -0.004 & 0.985 \\
\hline Lead 3 & -0.093 & 0.577 & -0.107 & 0.520 & -0.106 & 0.526 & -0.113 & 0.494 \\
\hline Lead 4 & 0.168 & 0.311 & $0.488 * * *$ & 0.003 & 0.176 & 0.287 & $0.501 * * *$ & 0.002 \\
\hline \multicolumn{9}{|c|}{ Foreign Upgrades } \\
\hline $\operatorname{Lag} 0$ & & & & & 0.219 & 0.690 & 0.237 & 0.651 \\
\hline $\operatorname{Lag} 1$ & & & & & -0.293 & 0.595 & -0.294 & 0.575 \\
\hline $\operatorname{Lag} 2$ & & & & & 0.106 & 0.847 & 0.089 & 0.866 \\
\hline Lead 1 & & & & & 0.521 & 0.343 & 0.532 & 0.310 \\
\hline Lead 2 & & & & & -0.233 & 0.672 & -0.233 & 0.657 \\
\hline \multicolumn{9}{|c|}{ Foreign Downgrades } \\
\hline $\operatorname{Lag} 0$ & & & & & 0.156 & 0.394 & 0.099 & 0.571 \\
\hline $\operatorname{Lag} 1$ & & & & & 0.273 & 0.139 & $-0.086^{*}$ & 0.076 \\
\hline $\operatorname{Lag} 2$ & & & & & 0.098 & 0.596 & $-0.042^{*}$ & 0.083 \\
\hline Lead 1 & & & & & $-0.536 * * *$ & 0.004 & $-0.499 * * *$ & 0.005 \\
\hline Lead 2 & & & & & -0.025 & 0.893 & $-0.009 * *$ & 0.032 \\
\hline Log Likelihood & \multicolumn{2}{|c|}{-15219.682} & \multicolumn{2}{|c|}{-17479.909} & \multicolumn{2}{|c|}{-15240.466} & \multicolumn{2}{|c|}{-18513.901} \\
\hline $\begin{array}{l}\text { Number of } \\
\text { observations }\end{array}$ & \multicolumn{2}{|c|}{4192} & \multicolumn{2}{|c|}{2012} & \multicolumn{2}{|c|}{4192} & \multicolumn{2}{|c|}{2012} \\
\hline
\end{tabular}

${ }^{2}$ The estimation is conducted through a random effect model using maximum likelihood. All specifications tests are undertaken prior to estimation. 
The estimation of Equation (1) for the entire sample period shows that rating upgrades increase next-day, own-country stock returns by one percent. After two days, reverting behavior is exhibited and stock returns decrease by $1.03 \%$. In the case of downgrades, own-country stock returns decrease by $0.41 \%$ after two days and increase by $0.32 \%$ after three days. The significant and negative lead coefficient (for downgrades) of one day supports the argument that credit rating agencies engage in pro-market-performance behavior.

The estimation of Equation (1) during the sovereign debt crisis period produces qualitative results that are very similar to those for the entire sample period. However, during the sovereign debt crisis period, there is some evidence of a mix of additional pro-market-performance rating changes occurring after one and four days.

To further investigate the different impacts of foreign upgrades and downgrades, we estimate Equation (2). Only the coefficients of foreign downgrades are significant; during the sovereign crisis period, in response to foreign downgrades, stock returns decrease by $0.09 \%$ the next day and $0.04 \%$ after two days. The significant and negative coefficient of lead variables demonstrates the existence of pro-market performance behavior by the credit rating agencies only in relation to negative ratings. Therefore, negative rating events impact own-country equity returns and cause significant spillovers to the equity markets of other countries, whereas upgrades have limited or insignificant impact (Kaminsky \& Schmukler, 2002; Brooks et al., 2004; Sy, 2004; Ferreira \& Gama, 2007; Hill \& Faff, 2010; Afonso, 2011; Alsakka \& ap Gwilym, 2013). This latter effect is more important during the sovereign debt crisis period.

\section{CONCLUSION}

This paper complements previous research on the impact of sovereign rating changes on stock markets. We examine the effect of international credit rating agency announcements on the domestic and cross-country stock market returns of four European countries, Greece, Portugal, Spain, and Italy, during the period from June 2008 to June 2013.

The results show that sovereign credit signals do have an impact on stock market returns, although there are differing reactions to news from the rating agencies. Importantly, the strongest market reactions are in response to own-country and foreign downgrades. During the sovereign debt crisis, negative announcements affected owncountry stock market returns and contributed to contagion. By examining the dynamic of lead variables related to rating changes, we find consistent empirical evidence that credit rating agencies exhibited pro-market-performance behavior during the entire sample period as well as during the crisis; i.e., announcing the rating changes afterwards.

\section{AUTHOR INFORMATION}

Ibrahim Fatnassi, University of Tunis, Higher Institute of Management, GEF-2A Lab, Tunis-Tunisia E-mail: ibrahim.fatnassi@isg.rnu.tn

Zied Ftiti, Associate Professor, IPAG Business School, IPAG Lab, Paris-France \& Associate Professor, Higher Institute of Management, GEF-2A Lab, Tunis-Tunisia. E-mail: Zied.Ftiti@isg.rnu.tn (Corresponding author)

Habib Hasnaoui, University of Tunis, Higher Institute of Management, GEF-2A Lab, Tunis-Tunisia E-mail: habib_hasnaoui@yahoo.fr

\section{REFERENCES}

1. Afonso, A., Furceri, D., \& Gomes, P. (2011, June). Sovereign credit ratings and financial markets linkages: Application to European data. (Working Paper No. 1347). Frankfurt, Germany: European Central Bank.

2. Alsakka, R., \& ap Gwilym, O. (2013). Rating agencies' signals during the European sovereign debt crisis: Market impact and spillovers. Journal of Economic Behavior \& Organization, 85(1), 144-162.

3. Alsakka, R., \& ap Gwilym, O. (2010). Leads and lags in sovereign credit ratings. Journal of Banking \& Finance, 34(5), 2614-2626. 
4. Brooks, R., Faff, R., Hillier, D., \& Hillier, J. (2004). The national market impact of sovereign rating changes. Journal of Banking \& Finance, 28(1), 233-250.

5. Bissoondoyal-Bheenick, E. (2012). Do sovereign rating changes trigger spillover effects? Research in International Business and Finance, 26(1), 79-96.

6. Bissoondoyal-Bheenick, E. (2004). Rating timing differences between the two leading agencies: Standard and Poor's and Moody's. Emerging Markets Review, 5(3), 361-378.

7. Cantor, R., \& Packer, F. (1996). Determinants and impact of sovereign credit ratings. Economic Policy Review, Federal Reserve Bank of New York, October, 37-53.

8. Christoher, R., Kim, S. J., \& Wu, E. (2012). Do sovereign credit ratings influence regional stock and bond market interdependencies in emerging countries? Journal of International Financial Markets, Institutions and Money, 22(4), 1070-1089.

9. Duff, A., \& Einig, S. (2009). Understanding credit ratings quality: Evidence from UK debt market participants. The British Accounting Review, 41(2), 107-119.

10. Ferreira, M. A., \& Gama, P. M. (2007). Does sovereign debt ratings news spill over to international stock markets? Journal of Banking \& Finance, 31, 3162-3182.

11. Ferri, G., Liu, L. G., Stiglitz, J. E. (1999). The procyclical role of rating agencies: Evidence from the East Asian crisis. Economic Notes: Economic Review of Banca Monte dei Paschi di Siena, 28, 335-355.

12. Hill, P., \& Faff, R. (2010). The market impact of relative agency activity in the sovereign ratings market. Journal of Business Finance \& Accounting, 37(9-10), 1309-1347.

13. Hooper, V. J., Hume, T. P., \& Kim, S. J. (2008). Sovereign rating changes-Do they provide new information for stock markets? Economic Systems, 32(2), 142-166.

14. Kasimati, E. (2011). Did the climb on the Greek sovereign spreads cause the devaluation of euro? Applied Economics Letters, 18(9), 851-854.

15. Li, H., Jeon, B. N., Cho, S. Y., \& Chiang, T. C. (2008). The impact of sovereign rating changes and financial contagion on stock market returns: Evidence from five Asian countries. Global Finance Journal, 19(1), 46-55.

16. Radelet, S., \& Sachs, J. (1998). The onset of the East Asian financial crisis. (Working Paper No. 6680). Cambridge, MA: National Bureau of Economic Research.

17. Reinhart, C. M., \& Rogoff, K. S. (2004). Serial default and the 'paradox' of rich-to-poor capital flows. American Economic Review, 94(2), 53-58.

18. Reisen, H., \& von Maltzan, J. (1999). Boom and bust and sovereign ratings. International Finance, 2(2), 273-293.

19. Sy, A. N. R. (2004). Rating the rating agencies: Anticipating currency crises or debt crises? Journal of Banking \& Finance, 28(11), 2845-2867.

20. Treepongkaruna, S., \& Wu, E. (2012). Realizing the volatility impacts of sovereign credit ratings information on equity and currency markets: Evidence from the Asian Financial Crisis. Research in International Business and Finance, 26(3), 335-352. 